\title{
Application of Crossword Puzzle Multimedia to Improve the Science Education Learning Process and Outcomes at Junior High Schools
}

\author{
Reni Marlina ${ }^{1^{*}}$, Erwina Oktavianty ${ }^{2}$, Haratua Tiur Maria Silitonga ${ }^{3}$, Novi Maulidia \\ Sandra ${ }^{4}$ \\ ${ }^{1}$ Biology Education, Tanjungpura University, Pontianak, Indonesia \\ 2,3 Physic Education,Tanjungpura University, Pontianak, Indonesia \\ ${ }^{4}$ Science Teacher at SMPN 1 Paloh, Sambas Regency, Indonesia \\ *e-mail: reni.marlina@fkip.untan.ac.id
}

\begin{abstract}
This study aims to improve the teaching and learning process and outcomes, improve the implementation process of instruction, and improve student learning outcomes by combining cooperative learning models with natural science educational crossword puzzle multimedia on the digestive system instructional material. The form of research used is Lesson study, which is designed in 2 cycles, each cycle having 1 meeting. At each meeting, students learnt in groups using the natural science educational crossword puzzle multimedia. The results showed that the application of educational crossword puzzle multimedia was carried out well in each cycle (100\%) with very strong criteria. Study results also described that the average activeness of students was $100 \%$ with very strong criteria. Based on the analysis of student achievement in the cycle I with an average score of 80.29, mastery of $82.61 \%$, and in the second Cycle 83.48 with mastery of $91.30 \%$, it can be concluded that thr application of natural science educational crossword puzzle multimedia supports the learning process for the better and improves student learning outcomes, especially in the material of digestive system.
\end{abstract}

Keywords: Crossword Puzzle Multimedia, Learning Outcomes, Learning Process

\section{Introduction}

Instruction according to the Ministry of Education and Culture No. 103/2014 is a process of an effort carried out by an individual to prevail whole of behaviour as a new change (Chiappetta \& Koballa, 2009). Instruction is also characterized by interactions between students as well as between students and teachers and learning resources in their environment. In order to be applied in instruction, teachers must play an active and innovative role (Ferrer, 2020). The achievement of learning objectives can be proven by one of which students leading to changes in behavior both intellectual, moral and social. The teaching objectives under the guidance of teachers in conducive conditions will have an impact on the optimization of learning outcomes (Sardiman, 2018). Learning outcomes can be characterized by the formation of students who are able to think at a high level, not merely memorizing and understanding a concept (Frank, 2003; Marlina et al., 2017; Posner et al., 1982). Achievement of student learning outcomes is measured using national standard questions known as the National Examination questions. This instrument can be defined as a collection of questions that describes the level of achievement of the educational process not only to measure each student but also to measure the whole education system (Chinapah, 1997). After 1990, assessments of learning outcomes have centered on what has been learned in schools while the major of focus in measuring the education quality in schools has centered on available facilities, material on the curriculum, availability of textbooks, and teacher training. All of these are some aspects that are expected to support the success of students in schools who need proper knowledge, skills, behavior, and attitude.

The implementation of the measurement of learning outcomes in schools has now been carried out both offline and online (Kurita et al, 2019). Changes in the implementation of the measurement that tend to be online-based lead to the creativity of teachers to create

\footnotetext{
${ }^{*}$ Corresponding author.
}

Received June 09, 2020; Accepted July 17, 2021; Available online December 25, 2021

This is an open access article under the CC BY-SA license. Copyright @ 2021 by Author. Published by Universitas Pendidikan Ganesha 
multimedia in accordance with the situation and conditions of the school and also based on games. One of the forms of teacher's creativity is preparing educational crossword puzzle multimedia. The selection of multimedia is based on a light and game-based assessment is required because it cannot be assumed that every student in school has meaningful knowledge, argumentative abilities, and skills that can be used as provisions to continue school at a higher level (Donovan \& Bransford, 2005). Furthermore, it is realized that many students only learn something at the level of knowledge and understanding (Driver et al., 2000). Competencies required in the curriculum require students to carry out the learning process mostly in the classroom so it needs to be supported by multimedia that can provide fun in understanding concepts. This is sufficient and in accordance with the demands of the technology-based 21st century, and the tendency of the assessment of students in the learning process has been centered on decentralization and dependent on school autonomy so that there is difficulty in setting the concept standards that must be mastered by students (Franco \& Deluca, 2019).

As for observations while teaching (5 through 9 September 2019), that the learning outcomes of students in the 7th grade VII and 8th grade increased if in the learning process appropriate learning media are used and in accordance with the subject material and available facilities. According to the teacher's statement in the field of science studies that low student learning outcomes were previously caused by the lack of maximum use of media resulting in the students' lack of interest and motivation. Lack of motivation and interest among the students has an impact on student activities and student learning outcomes. During this time the classroom instruction took place using the lecture method and using power point media. Even though the material had been delivered with power point media, students still only listened to the teacher's explanation, or the teacher centered classroom learning.

Several students of grades VII and VIII at the State Junior High School 1 Paloh said that the natural science material was difficult to understand because there were scientific names and terms in addition to the amount of material that needs to be learned. So the learning outcomes were still below the Minimum Mastery Criteria. The table below shows the average score of daily tests and the mastery learning percentage of grade VII students in the 2018/2019 and 2019/2020 academic years at the Paloh State Junior High School summarized from the list of student grades. Based on the average score in the material of the digestive system is the lowest of the other materials for the past 2 years. Based on the explanation, the researcher intended to improve performance and learning system that can improve student learning outcomes. Student learning outcomes can be improved by using instructional media that are in accordance with the material and involve a lot of students in teaching and learning process (Trianto, 2007). This is also declared that the involvement of students in learning can be achieved by providing opportunities for students to collaborate with other students in structured assignments involving instructional tools, one of which is the multimedia (Taniredja, 2011). Multimedia can improve students outcome in science subject in the material about human digestive in MI Muhammadiyah Donorejo, Magelang (Rahayu, 2020). Thats why the misconceptions material studyindigestive system or other metabolism material matter in human body needs to receive the attention from the educational practitioners and teachers (Istikomayanti \& Mitasari, 2017).

Multimedia developed by schools has referred to national standards, namely the presence of stimulus, creative and critical thinking characteristics with percentages of $40 \%$, $30 \%$, and $30 \%$, respectively (Braun, 2004). The formation of students who can think critically is an integrated part of science lessons (Aaron \& Haynes, 2005). With critical thinking, students will be able to argue correctly, interpret data correctly, and solve problems and make decisions correctly (Ennis, 1993; Facione et al., 1998; Pascarella \& Terenzini, 1991). Students should active play role in the teacing and learning process. Boredom will arise if students only listen (Clivaz, 2018). Generally, junior high school students tend to like learning activities while playing. One of them is by using educational games. One of the educational games is the science crossword game (Anderson \& Morgan, 2008). This media is a means that stimulates student activities to learn and stay engaged with learning material. 
The crossword puzzle is a type of intelligence game. Therefore, by using this crossword game, students will feel more challenged in working on problems provided by the teacher. In addition, students will better understand the material that has been taught, because this can overcome the boredom among students who only answer questions provided with a multiple-choice problem model or description. A crossword puzzle can be used as a medium to teach theoretical material. This is because in using this media students are trained to remember, understand, and match words according to the name and function of the tool. Basically, a crossword is an activity of remembering, searching and matching the right words not only according to the answer, but also the number of boxes provided. Natural Science exercises in the form of crosswords stimulate students' curiosity and train their independence by searching for answers to the questions / clues of the crosswords. The advantages of this multimedia-based crossword puzzle are among other things it can be done offline (not using the internet), it is in the form of a horizontal and vertical squares and blanks where the answers can be written based on the available number of blanks that will automatically bring up questions/statements, it has a duration of time and it can directly be scored when the activity is over (Johnson, 2019). Based on the background, focus of this research is improve the teaching and learning process and outcomes, improve the implementation process of instruction, and improve student learning outcomes by combining cooperative learning models with natural science educational crossword puzzle multimedia on the digestive system instructional material.

\section{Method}

The form of this study used is lesson study. Lesson Study (LS) originated in the Japanese language (from the word: jugyokenkyu) which is a systematic process used by Japanese teachers to test the instruction effectivity in order to increaseachievement (Huang et al., 2017). Kurita (2020) suggests that lesson study is valid research because it produces hypotheses obtained through the correct investigation process and meets the research criteria. This lesson study was conducted to improve student achievement on the material of the digestive system. The research was conducted VII Grade on students of State Junior High School 1 Paloh in the second semester of 2019/2020 academic year, with a total 26 students, consisting of 14 males and 9 females in 2 cycles. In the implementation, it was assisted by 6 observers, namely 3 Integrated Science teachers at State Junior High School 1 Paloh and 3 lecturers of the Faculty of Teacher Training and Education inUniversitas Tanjungpura. Preparations made before carrying out the lesson study was to make a plan to develop instructional tools used in the implementation of learning and learning achievement test questions. After that, seats were arranged in the classroom where the research was conducted.

The instructional tools were validated by two lecturers the Faculty of Teacher Training and Education in Universitas Tanjungpura and one science teacher of Stae Junior High School 1 Paloh. In addition, the test questions were tried out to find out if the test questions have sufficient reliability to be used in research with the K-R 20 (Kuder Richardson) formula. Student Worksheets and educational crossword puzzle multimedia were tried out beforehand on different class students. The results of the try-out were analyzed to determine whether or not it is feasible to be used in the study. The learning tools used in this study were syllabus, which was used as a reference material. Lesson Plan, Teaching materials in the form of natural science books, natural science educational crossword puzzle multimedia, which would be given to the students. Student Worksheets, as student exercises in teaching and learning. Test questions, to determine student learning mastery. Observation sheet, given to 6 observers who assisted the teacher in observing the process of implementing instruction. The stages of this researchcomprised the four stagesas a lesson study cycle (Figure 1). 


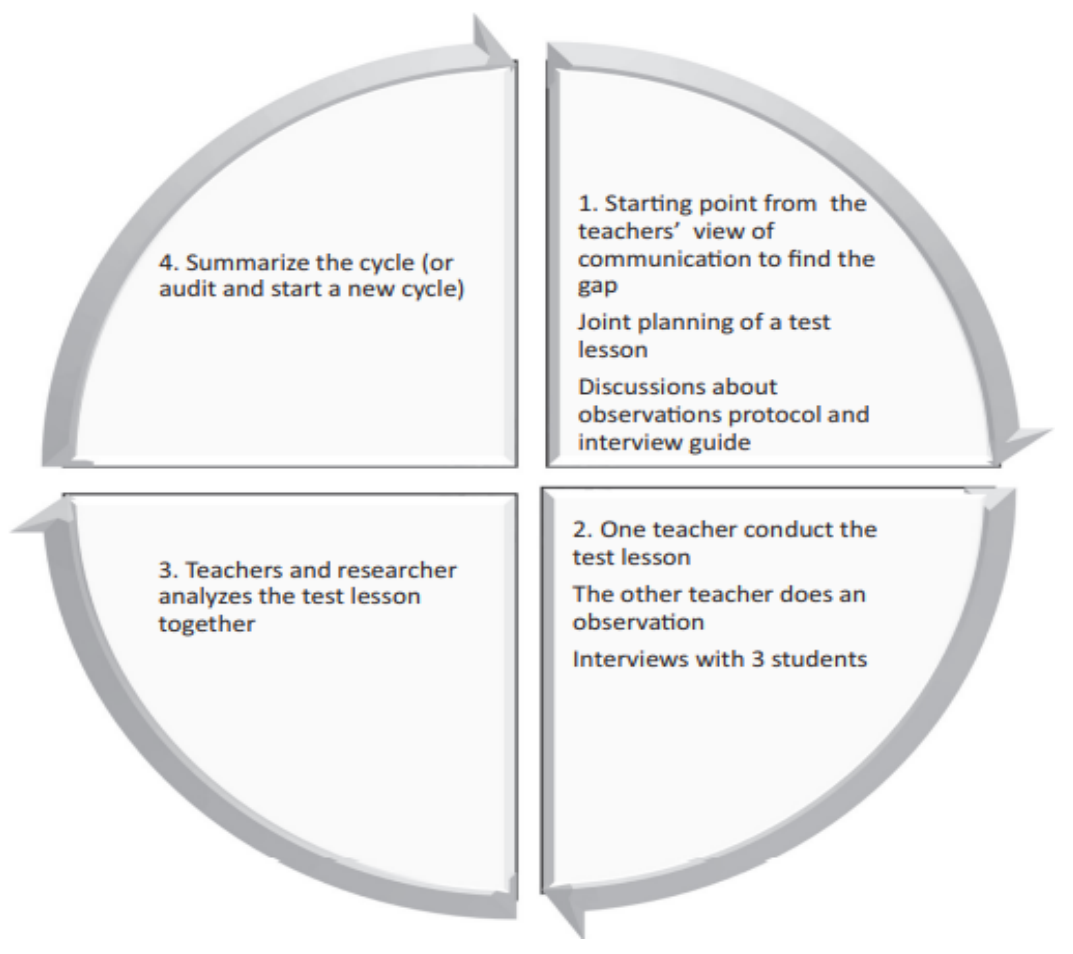

Figure 1. Step in Lesson Study

The lesson study was designed in two cycles, each consisting of 1 meeting. In each meeting, 4 stages of the main activities that were carried out were plan, do, see, and reflection (redesign). Data analysis was performed on the observation sheet, student worsheets and test questions. The same analysis on student worksheets and test questions was performed, namely counting the number of individual or group scores. In the test questions, the percentage of students learning mastery was determined with the Minimum Mastery Criteria of 65 . The research would be regarded as successful when $70 \%$ of students in the class could achieve the Minimum Mastery Criteria score.

\section{Result and Discussion}

\section{Results}

To find out the process of implementing the instruction, observation sheets were used. The observers would observe the process of using the application of educational crossword puzzle multimedia. The observation results of the instructional process carried out by the observers in 2 cycles are abridge in Table 2 .

Table 2. The Process of Instruction through Cooperative Learning Using the Natural Science Educational Crossword Puzzle

\begin{tabular}{|c|c|c|c|c|c|c|}
\hline \multirow[t]{2}{*}{ No } & \multirow[b]{2}{*}{$\begin{array}{l}\text { Phase of } \\
\text { Instruction }\end{array}$} & \multirow{2}{*}{$\begin{array}{c}\text { Item of } \\
\text { Assessment } \\
\text { Aspect }\end{array}$} & \multicolumn{2}{|c|}{ Cycle I } & \multicolumn{2}{|c|}{ Cycle II } \\
\hline & & & $\begin{array}{c}\text { Percentage } \\
(\%)\end{array}$ & Criteria & $\begin{array}{c}\text { Percentage } \\
(\%)\end{array}$ & Criteria \\
\hline 1 & $\begin{array}{l}\text { Introducing Learning } \\
\text { Objectives and } \\
\text { Motivating Students }\end{array}$ & 1,2 and 3 & 100 & $\begin{array}{l}\text { Very } \\
\text { Strong }\end{array}$ & 100 & $\begin{array}{l}\text { Very } \\
\text { Strong }\end{array}$ \\
\hline 2 & $\begin{array}{l}\text { Presenting } \\
\text { Information }\end{array}$ & 4,5 and 6 & 100 & $\begin{array}{l}\text { Very } \\
\text { Strong }\end{array}$ & 100 & $\begin{array}{l}\text { Very } \\
\text { Strong }\end{array}$ \\
\hline 3 & $\begin{array}{l}\text { Organizing Students } \\
\text { Into Study Groups }\end{array}$ & 7 & 100 & $\begin{array}{l}\text { Very } \\
\text { Strong }\end{array}$ & 100 & $\begin{array}{l}\text { Very } \\
\text { Strong }\end{array}$ \\
\hline 4 & $\begin{array}{l}\text { Guiding Work and } \\
\text { Study Groups }\end{array}$ & $\begin{array}{l}8,9,10,11 \\
\text { and } 12\end{array}$ & 100 & $\begin{array}{l}\text { Very } \\
\text { Strong }\end{array}$ & 100 & $\begin{array}{l}\text { Very } \\
\text { Strong }\end{array}$ \\
\hline
\end{tabular}




\begin{tabular}{|c|c|c|c|c|c|c|}
\hline \multirow[t]{2}{*}{ No } & \multirow[b]{2}{*}{$\begin{array}{l}\text { Phase of } \\
\text { Instruction }\end{array}$} & \multirow{2}{*}{$\begin{array}{c}\text { Item of } \\
\text { Assessment } \\
\text { Aspect }\end{array}$} & \multicolumn{2}{|c|}{ Cycle I } & \multicolumn{2}{|c|}{ Cycle II } \\
\hline & & & $\begin{array}{c}\text { Percentage } \\
(\%)\end{array}$ & Criteria & $\begin{array}{c}\text { Percentage } \\
(\%)\end{array}$ & Criteria \\
\hline 5 & Evaluation & 13 and 14 & 100 & $\begin{array}{l}\text { Very } \\
\text { Strong }\end{array}$ & 100 & $\begin{array}{l}\text { Very } \\
\text { Strong }\end{array}$ \\
\hline 6 & Giving reward & 15 & 100 & $\begin{array}{l}\text { Very } \\
\text { Strong }\end{array}$ & 100 & $\begin{array}{l}\text { Very } \\
\text { Strong }\end{array}$ \\
\hline & Average & & 100 & $\begin{array}{c}\text { Very } \\
\text { Strong }\end{array}$ & 100 & $\begin{array}{c}\text { Very } \\
\text { Strong }\end{array}$ \\
\hline
\end{tabular}

Based on the data from the observations made by the observers, the results were $100 \%$ in the first and second cycles respectively with Very Strong criteria. It means the observers saw in each phase the learning process carried out by the teacher was in accordance with the lesson plan. In addition to the data above, Table 3 presents the results of observations on student activities regarding use of educational crossword puzzle multimedia.

Table 3. Results of Observation on Student Activeness in the Use of Natural Science Educational Crossword Puzzle Multimedia

\begin{tabular}{|c|c|c|c|c|c|}
\hline \multirow[t]{2}{*}{ No } & \multirow[b]{2}{*}{ Student Activeness } & \multicolumn{2}{|c|}{ Cycle I } & \multicolumn{2}{|c|}{ Cycle II } \\
\hline & & $\begin{array}{c}\text { Percentage } \\
(\%)\end{array}$ & Criteria & $\begin{array}{c}\text { Percentage } \\
(\%)\end{array}$ & Criteria \\
\hline 1 & $\begin{array}{l}\text { Students pay attention to the } \\
\text { teacher in demonstrating the } \\
\text { use of natural science } \\
\text { educational crossword puzzle } \\
\text { multimedia }\end{array}$ & 100 & $\begin{array}{l}\text { Very } \\
\text { Strong }\end{array}$ & 100 & $\begin{array}{l}\text { Very } \\
\text { Strong }\end{array}$ \\
\hline 2 & $\begin{array}{l}\text { Students study seriously when } \\
\text { using natural science } \\
\text { educational crossword puzzle } \\
\text { multimedia }\end{array}$ & 100 & $\begin{array}{l}\text { Very } \\
\text { Strong }\end{array}$ & 100 & $\begin{array}{l}\text { Very } \\
\text { Strong }\end{array}$ \\
\hline 3 & $\begin{array}{l}\text { Students discuss to manage } \\
\text { the problems on the media }\end{array}$ & 100 & $\begin{array}{l}\text { Very } \\
\text { Strong }\end{array}$ & 100 & $\begin{array}{l}\text { Very } \\
\text { Strong }\end{array}$ \\
\hline 4 & $\begin{array}{l}\text { Students discuss together to } \\
\text { fiks the problems on student } \\
\text { worksheets }\end{array}$ & 100 & $\begin{array}{l}\text { Very } \\
\text { Strong }\end{array}$ & 100 & $\begin{array}{l}\text { Very } \\
\text { Strong }\end{array}$ \\
\hline 5 & $\begin{array}{l}\text { Students use crossword puzzle } \\
\text { multimedia when answering } \\
\text { student worksheets }\end{array}$ & 100 & $\begin{array}{l}\text { Very } \\
\text { Strong }\end{array}$ & 100 & $\begin{array}{l}\text { Very } \\
\text { Strong }\end{array}$ \\
\hline 6 & $\begin{array}{l}\text { Students read all the material } \\
\text { in student worksheets }\end{array}$ & 100 & $\begin{array}{l}\text { Very } \\
\text { Strong }\end{array}$ & 100 & $\begin{array}{l}\text { Very } \\
\text { Strong }\end{array}$ \\
\hline 7 & $\begin{array}{l}\text { Students are enthusiastic about } \\
\text { the lesson }\end{array}$ & 100 & $\begin{array}{l}\text { Very } \\
\text { Strong }\end{array}$ & 100 & $\begin{array}{l}\text { Very } \\
\text { Strong }\end{array}$ \\
\hline 8 & $\begin{array}{l}\text { Students present the results of } \\
\text { the discussion well }\end{array}$ & 100 & $\begin{array}{l}\text { Very } \\
\text { Strong }\end{array}$ & 100 & $\begin{array}{l}\text { Very } \\
\text { Strong }\end{array}$ \\
\hline & Average & 100 & $\begin{array}{l}\text { Very } \\
\text { Strong }\end{array}$ & 100 & $\begin{array}{l}\text { Very } \\
\text { Strong }\end{array}$ \\
\hline
\end{tabular}

Based on the data from the observations made by the observers, the students were $100 \%$ active with Very Strong criteria. 'Very Strong' means that students were actively involved in the teaching and learning process including carrying out the direction of the teacher. Achievement tests were used to determine student learning outcomes, which were given at the end of each action cycle. Students are scaled as accomplished if their scores meet the Minimum Mastery Criteria of 65 . A learning process is regarded as being successful 
if the percentage of students who reach the minimum criteria is at least $70 \%$, in accordance with the achievement of performance indicators. In this study, cycle I discussed cells and tissues on June 13, 2012, followed by cycle II which discussed organs, organ systems and organisms on June 15,2012 . The results of research that present data on student achievementshows in Table 4 below.

Table 4. Learning Outcomes of Grade VII Students Each Cycle.

\begin{tabular}{|c|c|c|c|c|c|c|c|c|}
\hline \multirow{3}{*}{ No } & \multirow{3}{*}{$\begin{array}{l}\text { Student } \\
\text { Number }\end{array}$} & \multirow{3}{*}{$\begin{array}{l}\text { Stud } \\
\text { ent } \\
\text { Code }\end{array}$} & \multicolumn{6}{|c|}{ Student Achievement } \\
\hline & & & \multicolumn{3}{|c|}{ Cycle I } & \multicolumn{3}{|c|}{ Cycle II } \\
\hline & & & Sco re & Gra de & Remark & Score & Grade & Remark \\
\hline 1 & 11159 & SR & 12 & 80.00 & Accomplished & 9 & 90 & Accomplished \\
\hline 2 & 11143 & G & 9 & 60.00 & Unaccomplished & 5 & 50 & Unaccomplished \\
\hline 3 & 10136 & F M & 11 & 73.33 & Accomplished & 8 & 80 & Accomplished \\
\hline 4 & 11140 & $A G$ & 12 & 80.00 & Accomplished & 7 & 70 & Accomplished \\
\hline 5 & 11141 & $A R$ & 13 & 86.67 & Accomplished & 7 & 70 & Accomplished \\
\hline 6 & 11142 & $A Q$ & 13 & 86.67 & Accomplished & 10 & 100 & Accomplished \\
\hline 7 & 11145 & B M & 14 & 93.33 & Accomplished & 9 & 90 & Accomplished \\
\hline 8 & 11146 & JR & 12 & 80.00 & Accomplished & 9 & 90 & Accomplished \\
\hline 9 & 11147 & $\mathrm{MB}$ & 8 & 53.33 & Unaccomplished & 6 & 60 & Unaccomplished \\
\hline 10 & 11150 & $M X$ & 12 & 80.00 & Accomplished & 9 & 90 & Accomplished \\
\hline 11 & 11149 & $\mathrm{MK}$ & 11 & 73.33 & Accomplished & 10 & 100 & Accomplished \\
\hline 12 & 11151 & $M L$ & 12 & 80.00 & Accomplished & 7 & 70 & Accomplished \\
\hline 13 & 11161 & $M V$ & 11 & 73.33 & Accomplished & 8 & 80 & Accomplished \\
\hline 14 & 11148 & $\mathrm{M} \mathrm{M}$ & 15 & 100.00 & Accomplished & 10 & 100 & Accomplished \\
\hline 15 & 11153 & $R E$ & 13 & 86.67 & Accomplished & 8 & 80 & Accomplished \\
\hline 16 & 10135 & $S A$ & 12 & 80.00 & Accomplished & 10 & 100 & Accomplished \\
\hline 17 & 11154 & S W & 15 & 100.00 & Accomplished & 8 & 80 & Accomplished \\
\hline 18 & 11160 & A T & 11 & 73.33 & Accomplished & 7 & 70 & Accomplished \\
\hline 19 & 11156 & S T & 8 & 53.33 & Unaccomplished & 7 & 70 & Accomplished \\
\hline 20 & 11157 & TS & 15 & 100.00 & Accomplished & 9 & 90 & Accomplished \\
\hline 21 & 11158 & Y A & 14 & 93.33 & Accomplished & 9 & 90 & Accomplished \\
\hline 22 & & I C & 15 & 100.00 & Accomplished & 9 & 90 & Accomplished \\
\hline \multirow[t]{2}{*}{23} & & R S & 9 & 60.00 & Unaccomplished & 8 & 80 & Accomplished \\
\hline & Average & & 12.04 & 80.29 & & 8.22 & 82.17 & \\
\hline \multicolumn{5}{|c|}{$\Sigma$ Accomplished } & 19 & \multicolumn{2}{|c|}{$\begin{array}{c}\Sigma \\
\text { Accomplished }\end{array}$} & 21 \\
\hline \multicolumn{5}{|c|}{ Mastery (\%) } & 82.61 & Mas & ry (\%) & 91.30 \\
\hline
\end{tabular}

Based on the Table above showing the student learning outcomes, in the first cycle $82.61 \%$ of students reached the minimum mastery, while in the second cycle mastery rate is higher namely $91.30 \%$. Students are regarded as reaching the minimum mastery if they get a score of $\geq 65$ (Minimum Mastery Criteria of 65). The average score in the cycle $I$ is 80.29 , while in the cycle II 82.17. From the data above, it appears that the data are an increase from first cycle to second cycle.

\section{Discussion}

In an effort to improve the learning process in order to increase learning outcomes at the State Junior High School 1 Paloh, a treatment in the first cycle was designed with the application using educational crossword puzzle multimedia on the digestive system material. In planning this first treatment, preparation of learning tools were made in the form of Lesson Plan, Student Worksheets (LKPD), and educational crossword puzzle multimedia, and the formation of heterogeneous student learning groups. To find out about student learning outcomes, test questions, observation sheets of the learning implementation process and student activity sheets in using educational crossword puzzle multimedia were prepared to 
be used by the observers. The treatment in the first cycle lasted for 1 meeting $(2 \times 40$ minutes), which was carried on December 13, 2019. The material discussed in the first cycle was the definitions and organs in the digestive system. At the previous level, students already knew a little about the digestive organs, but at this stage the teacher tried to bring back what students already knew before. Because students had never made an evaluation using natural science educational crossword puzzle multimedia before, at the beginning of instruction the teacher allocated time to discuss how to use the media.

In previous learning activities, students rarely interacted with other fellow students, so this time they were grouped and told to interact with their peers so that they can learn together and interact well with the media and their peers. Learning is a change in behavior of individuals due to interaction between individuals, as well as individuals and their environment in order to build better interaction with their environment (Cerini et al., 2003). The Cycle I Lesson Plan contained instructional settings where students were directed to interact more with their friends and environment. In the cooperative learning model there are 6 cooperative phases namely introducing the aims and motivating students, describe the information, grouping students into study groups, work together and study groups, evaluating and giving rewards. The first Phase was to introduce objectives and motivate students. In the first cycle, this phase was carried out well in accordance with observations made by the observers. The teacher provided apperception by cutting paper into small pieces, so as to bring back students' knowledge about the digestive organs. Then the teacher introduced the learning objectives and the natural science educational crossword multimedia. This introduction was made to make students curious about the natural science educational crossword puzzle multimedia, thus motivating students to learn seriously. Students were enthusiastic and happy with instruction using a computer.

In the second Phase, information was presented. The information presented in this phase contained explanation of earlier material to students and then the teacher explained how to use the media from beginning to end which to answer the questions. Students listened to the teacher attentively. This can be seen on the student activity sheets. Phase 3 was used to arrange students into study groups, as these groups had been determined based on the results of the first semester tests. Students were in divided into heterogeneous groups because group learning provides opportunities for students with different backgrounds and conditions to work depending on each other on shared assignments, and through the use of cooperative reward structures, learning to respect one another (Kirschner et al., 2006; Trianto, 2011). In the third Phase, the teacher only asked students to sit in accordance with their respective learning groups, and the teacher displayed the educational crossword puzzle multimedia so that students can learn quickly. In order for focus group activities, it is necessary to provide brief guidelines as activity guideline. Phase 4 was used to guide the group to work and study. After all students were ready with the media, the teacher checked students' understanding of their use, that is, the teacher and students together use the media as a new experience. When students already understood, the teacher invited each group to learn about it. In the first cycle, students still asked a lot questions, especially on how to use the media and fill in student worksheets. Good group work is very much needed in cooperative learning. Social skills are needed in mutual cooperation work such as leadership, communication skills, trusting others and managing conflict (Trianto, 2007). There are so many things that students will learn in group learning.

Phases 5 and 6 were for evaluation and giving reward. The evaluation was carried out in the form of student worksheets evaluation, and the results of scores obtained by students in answering questions in the educational crossword puzzle media. Rewards were given to groups that scored the highest in which they received a bonus score of 5 points. In the implementation, Phases 5 and 6 ran smoothly. At the end of the study, a learning achievement test is performed to see the students' achievement in understanding the material, the evaluation of learning outcomes aims to determine the level of success achieved by students after participating in a learning activity (Dimyati \& Mudjiono, 1999). The observations in the first cycle were divided into observation of the process of implementing instruction and student activeness observation carried out by 6 observers namely the science 
teachers of State Junior High School 1 Paloh and students of the lecturers of the Teacher Training and Education Faculty of Tanjungpura University. Observations of the learning process are carried out to see how the learning process takes place. The implementation of the teaching and learning process can be concluded as the interaction of teachers and students in order to deliver teaching materials to students to achieve instructional objectives (Suryosubroto, 2009). So, the observations of the learning implementation process in all phases of instruction in the lesson study design were carried out well (Utsumi \& Ando, 2019). The teacher had no significant obstacles and the observers also observed that the learning process took place in accordance with the lesson plan.

In addition to observing the learning process, there are also observations of student activities. In previous instruction there was less direct interaction between students and the media, so observations of student activities were carried out to see how students interacted with friends and the media used (Mayrhofer, 2019). Without activities, the learning process might not take place properly (Sardiman, 2018). The combination of collaborative learning that makes students work in heterogeneous groups and with crossword puzzle like the natural science educational crossword puzzle multimedia is very helpful for students to communicate with friends, and students feel they can learn effectively (Claire, 2010). Learning with friends is also necessary because it can be more successful than learning with teachers (Manurung, 2013).

Reflections were made by the teacher or researcher and the observers regarding obstacles or disadvantage that occurred in the process of carrying out the instruction (Davis et al., 2009; Tuan et al., 2005). There were several obstacles, but they could still be overcome by the teacher and did not cause learning activities to stop. Based on the results of the reflections on the first cycle of treatment, it can be concluded that the implementation of the instruction was appropriate and achieved the target of performance indicators that is $70 \%$. Student learning outcomes showed that the treatment done in the form of multimedia applications of the educational crossword puzzle could improve student interaction with other fellow students and the media so that they could learn more actively which had an impact on learning outcomes (Arifianto, 2014; Jr \& Bautista, 2019). The paradigm that expects a class instruction to be student centered can be done by applying a group learning model (Fathonah, 2013; Suryosubroto, 2009). Working with small groups is an embodiment of active learning, and in addition, class discussion plays a very important role in active learning (Silberman, 2009). Group learning can improve student performance on academic assignments, excel at helping students understand difficult concepts and help foster students' critical thinking (Lueddeke, 2003; Sarmiento, 2010; Trianto, 2007).

The implementation of the learning process and the activeness of students learning, especially in the use of media and understanding the material had an impact on student learning outcomes (Frankham et al., 2015) as shown in Table 4. These results indicate that in the first cycle of student learning outcomes, the students' average score was 80.29 with 19 students reaching the minimum mastery and the percentage of mastery being $82.61 \%$. In cycle II, the average score 2.17 with a total of 21 students reaching the minimum mastery and the percentage of mastery being $91.30 \%$. As for the learning outcomes obtained from the post test at the end of instruction in stage 2, there were 21 students who accomplished the mastery, with an average student learning outcome of 82.17 and with a percentage of mastery of $91.30 \%$. These results indicate that in this second cycle, students understood how to learn by using natural science educational crossword puzzle media, so they were able to study seriously and obtained good results.

Based on the data analysis regarding the results of the tests obtained by students, namely in the first cycle, there were 4 students who did not accomplish the mastery and then continued with the second cycle. In cycle II, there were 2 students who did not reach the mastery, based on the observers' notes that all students paid attention to the teacher and cooperated in study groups. The two students who failed were those who did not pay attention to or did not concentrate on the teacher's explanation and did not cooperate well in study groups. In addition, the other 2 students in cycle I also failed, but in cycle II they reached the minimum mastery. These students were those who did not get along with their 
peers and in the first cycle it appears that they were not active because of social inequalities. However, in the second cycle, the gap disappeared, and it appears that 2 students became active in the use of media, and were able to interact well with their group members.

In cycle I there were 15 questions, and for question 5 there were 10 students who answered incorrectly, and for question 14 there were 9 students who answered incorrectly. In cycle II, there were 10 questions, and for question 4 there were 12 students who answered incorrectly. In the media, there is an explanation of the material and is related to the test questions. Students who got the answer wrong were because they did not pay attention or lacked concentration in understanding the teacher's explanation and the educational crossword puzzle multimedia (Orawiwatnakul, 2013; Perkins, 1992; Shirazi, 2017). The learning outcomes showed an increase in Cycle II compared with Cycle I. The increase in learning outcomes was affected by several factors, namely the learning model and learning media used by the teacher in the instructional process in class. Therefore, the application of natural science educational crossword puzzle multimedia was able to improve student learning outcomes on the digestive system material in Grade VII of the State Junior High School 1 Paloh. The teachers stated that students often had a different view of what Digestive system was and how to increase students' knowledge. For teachers in general, working with Crossword Puzzle Multimedia is central; students are influenced by their habituation in teaching and learning stategy. For teacher teams, however, teaching with multimedia means learning individually and quietly (De Brabander \& Glastra, 2018). For teacher science, that may conduct communication andhigher order thinking skill of students.

\section{Conclusions and Suggestions}

Based on the results of data analysis, it can be concluded that the implementation of lesson study in Cycle I and Cycle II went very strong criteria. The application of natural science of educational crossword puzzle multimedia is able to support a good learning process where the activeness of students includes learning and collaborating with friends in Cycle I and Cycle II with Very Strong criteria. Group learning with natural science of educational crossword puzzle multimedia is able to improve the students' mastery in the form of increased student learning outcomes. In the second cycleoutcomed increased compared to the previous year. Therefore, the application of lesson study with natural science of educational crossword puzzle multimedia can be used as an alternative in instructioanl strategies, especially in the natural science material.

\section{Acknowledgements}

We would like to thank Indonesian Ministry of education and culture for funding this research. to the Head of research and community services office and Teacher Training and Education Faculty-Tanjungpura University science teacher, and students of Junior high school in Paloh West Kalimantan Provence for the contribution during this research.

\section{References}

Aaron, L., \& Haynes, K. (2005). Critical Thinking: A Method for Program Evaluation. Radiologic Science \& Education, 10(2), 5-11.

Anderson, P., \& Morgan, G. (2008). Developing Tests and Questionnaires for a National Assessment of Educational Achievement (Vol. 2). World Bank. https://www.academia.edu/27761840/Developing_tests_and_questionnaires_for_a_n ational_assessment_of_educational_achievement.

Arifianto, P. N. (2014). Use of Media Crossword Game Against Deaf Children Learning Outcomes In SLB-AB Kemala Bhayangkari 2 Gresik. Surabaya State University.

Braun, H. (2004). Reconsidering the impact of high-stakes testing. Education Policy Analysis Archives, 12(1). https://doi.org/10.14507/epaa.v12n1.2004.

Cerini, B., Murray, I., \& Reiss, M. (2003). Student Review of The Science Curriculum: Major 
Findings. Publication Science.

Chiappetta, E., \& Koballa, T. R. (2009). Science instruction in the middle and secondary schools: Developing fundamental knowledge and skills, 7th edn. Pearson Education Inc.

Chinapah, V. (1997). Handbook On Monitoring Learning Achievement Towrds Capacity Building. UNESCO.

Claire, E. (2010). Easy English Crossword Puzzles Easy Songs for English Language Learners. Eardley Publication Saddle Brook.

Clivaz, S. (2018). Lesson Study As a Fundamental Situation for The Knowledge of Teaching. International Journal for Lesson and Learning Studies, 7(3), 172-183. https://doi.org/10.1108/IJLLS-03-2018-0015.

Davis, T., Shepherd, B., \& Zwiefelhofer, T. (2009). Reviewing for Exams: Do Crossword Puzzles Help in the Success of Student Learning? Journal of Effective Teaching, 9(3), 4-10. https://eric.ed.gov/?id=EJ1092108.

De Brabander, C. J., \& Glastra, F. J. (2018). Testing a unified model of task-specific motivation: How teachers appraise three professional development activities. Frontline Learning Research, 6(1), 54-76. https://doi.org/10.14786/flr.v6i1.342.

Dimyati, \& Mudjiono. (1999). Belajar dan Pembelajaran.

Donovan, M., \& Bransford, J. (2005). How Student Learn Science In The Classroom. National Academies Press.

Driver, R., Newton, P., \& Osborne, J. (2000). Establishing The Norms Of Scientific Argumentation In Classrooms. Science Education, 84(3), 287. https://doi.org/10.1002/(sici)1098-237x(200005)84:3<287::aid-sce1>3.3.c0;2-1.

Ennis, R. H. (1993). Critical Thinking Assessment. Theory Into Practice, 32(3), 179-186. https://doi.org/10.1080/00405849309543594.

Facione, P. A., Blohm, S. W., Hoeward, K. \&, \& Giancarlo, C. A. (1998). The California Critical Thinking in Nursing. Holistic Nursing Pactice, 10(3), 41-53.

Fathonah, R. (2013). Study Comparative Use of Media Puzzle with Card On Chemistry Learning Through Contextual Te aching and Learning Approach To Student Achievement in SMP N 2 Ngadirojo. Chemical Education Journal, 2(3).

Frank, S. (2003). Reel Reality: Science Consultants In Hollywood. Science as Culture, 12(4), 427-469. https://doi.org/10.1080/0950543032000150319.

Frankham, G. J., Hinds, M. C., \& Johnson, R. N. (2015). Development of 16 forensically informative microsatellite loci to detect the illegal trade of broad headed snakes (Hoplocephalus bungaroides). Conservation Genetics Resources, 7(2), 533-535. https://doi.org/10.1007/s12686-014-0414-2.

Hodgson, C., \& Pyle, K. (2010). A Literature Review Of Assessment For Learning In Science. National Foundation for Education Research.

Huang, R., Fang, Y., \& Chen, X. (2017). Chinese Lesson Study: A Deliberate Practice, A Research Methodology, And An Improvement Science. International Journal for Lesson \& Learning Studies, 6(4), 270-282. https://doi.org/10.1108/IJLLS-08-20170037.

Istikomayanti, Y., \& Mitasari, Z. (2017). Student's Misconception of Digestive System Materials in MTs Eight Grade of Malang City and the Role of Teacher's Pedadogic Competency in MTs. Jurnal Pendidikan Biologi Indonesia, 3(2), 103. https://doi.org/10.22219/jpbi.v3i2.4326.

Jr, D. V. R., \& Bautista, J. R. (2019). Filipino Students ' Preferred Motivational Strategies in Science: A Cross-Sectional Survey. International Journal on Social and Education Sciences, 3(2), 358-372. https://online-journal.unja.ac.id/irje/article/view/6828.

Kellaghan, T. (2003). Local, national, and international levels of system evaluation: Introduction. In T. Kellaghan \& D. L. Stufflebeam (Eds.), International handbook of educational evaluation. Kluwer Academic.

Kirschner, P. A., Sweller, J., \& Clark, R, E. (2006). Why Minimal Guidance During Instruction Does Not Work: An Analysis of the Failure of Constructivist, Discovery, ProblemBased, Experiential, and Inquiry-Based Teaching. Educational Psychologist, 41(2), 
111-127,. https://doi.org/10.1207/s15326985ep4102.

Lueddeke, G. R. (2003). Professionalising Teaching Practice In Higher Education: A Study of Disciplinary Variation And "Teaching-Scholarship." Studies in Higher Education, 28(2), 213-228. https://doi.org/10.1080/0307507032000058082.

Manurung, Y. L. (2013). Pendidikan Karakter di Sekolah Membangun Karakter dan Kepribadian Anak. Journal Pshycology, Personality and Social Psychology, 10(2).

Marlina, R., Puspaningrum, H., \& Hamdani. (2017). Differentiation of test items between the high school biology olimpiad in north kayong and the national science olimpiad. Jurnal Pendidikan IPA Indonesia, 6(2), 245-251. https://doi.org/10.15294/jpii.v6i2.10679.

Mayrhofer, E. (2019). Lesson study and teachers' beliefs: How a Bourdieuian perspective could make a difference. International Journal for Lesson and Learning Studies, 8(1), 19-33. https://doi.org/10.1108/IJLLS-11-2018-0091.

Orawiwatnakul, W. (2013). Crossword Puzzles As a Learning Tool For Vocabulary Development. Electronic Journal of Research in Educational Psychology, 11(2), 413428. https://doi.org/10.14204/ejrep.30.12186.

Pascarella, E. T., \& Terenzini, P. T. (1991). How College Affects Students: Findings and Insights from Twenty Years of Research. Jossey-Bass.

Perkins, D. (1992). Smart Schools: Better Thinking and Learning for Every Child. The Free Press.

Posner, G. J., Strike, K. a., Hewson, P. W., \& Gertzog, W. a. (1982). Accommodation of a scientific conception: Toward a theory of conceptual change. Science Education, 66(2), 211-227. https://doi.org/10.1002/sce.3730660207.

Rahayu, M. (2020). Development of Cyberlink Power Director Based Learning Media in the Material of Human Digestive System. 3(1), 13-17. https://jurnal.untidar.ac.id/index.php/ijobe/article/view/2294.

Sardiman, A. M. (2018). Interaksi dan Motivasi Belajar Mengajar. Rajawali Press.

Sarmiento, C. Q. (2010). Teaching Strategies To Enhance Science Learning Among Diverse And Multicultural Learners. JPAIR Multidisciplinary Research Journal, 4(1). https://www.ejournals.ph/article.php?id=7432.

Schraw, G. J., \& Robinson, D. . (2011). Assessment of Higher Order Thinking Skills. Information Age Publishing.

Shirazi, S. (2017). Student Experience of School Science. International Journal of Science Education, 39(14), 1891-1912. https://doi.org/10.1080/09500693.2017.1356943.

Silberman, M. (2009). Active Learning. Intan Mandiri.

Slameto. (2010). Belajar dan Faktor-Faktor yang Mempengaruhinya. Rineka Cipta.

Suryosubroto, B. (2009). Proses Belajar Mengajar di Sekolah. Rineka Cipta.

Syamsuri, I., \& Ibrohim. (2008). Lesson Study. FMIPA UM.

Taniredja, T. et al. (2011). Model-model Pembelajaran Inovatif. Alfabeta.

Trianto. (2007). Model-model Pembelajaran Inovatif Berorientasi Kontruktivistik (1st ed.). Prestasi Pustaka.

Trianto. (2011). Mendesain Model Pembelajaran Inovatif-Progresiv. Kencana Prenada Media.

Tuan, H. L., Chin, C. C., \& Shieh, S. H. (2005). The Development Of a Questionnaire To Measure Students' Motivation Towards Science Learning. International Journal of Science Education, 27(6), 639-654. https://doi.org/10.1080/0950069042000323737.

Utsumi, Y., \& Ando, T. (2019). Teacher Needs and Relevant Factors for Teaching JiritsuKatsudo in Special Needs Schools for Children with Physical Disabilities. Journal of Special Education Research, 7(2), 79-88. https://doi.org/10.6033/specialeducation.7.79. 